\section{SUVREMENO TRŽIŠTE DROGA - UTJECAJ DIGITALNOG TRŽIŠTA NA STRUKTURU I DINAMIKU TRŽIŠTA DROGA}

Pregledni članak

Primljeno: travanj, 2020.

Prihvaćeno: lipanj, 2021.

UDK: 616.83:343.575

DOI 10.3935/ljsr.v28i2.372

Anita Jandrić

Nišević ${ }^{1}$

https://orcid.org/0000-0002-

9076-0403

Dalibor Doležal²

https://orcid.org/0000-0003-

1558-5905

Tihana Novak ${ }^{3}$

Edukacijsko-rehabilitacijski

fakultet

Sveučilište u Zagrebu

Ključne riječi:

suvremeno tržište droga,

digitalno trǔište,

kripto tržište, dark net

1 Izv. prof. dr. sc. Anita Jandrić Nišević, socijalni pedagog, e-mail: anita.jandric. nisevic@erf.unizg.hr

2 Izv. prof. dr. sc. Dalibor Doležal, socijalni pedagog, e-mail: dalibor.dolezal@erf. unizg.hr

3 Doc. dr. sc. Tihana Novak, socijalni pedagog, e-mail: tihana.novak@erf.unizg.hr 
Istraživanja sugeriraju da razvojem kripto tržišta tradicionalna tržišta drogom neće nestati već će se oba tržišta međusobno nadopunjavati pri čemu će djelovanje na digitalnom tržištu biti učestalije zbog veće mogućnosti zaštite identiteta njegovih glavnih aktera. Aktivnosti usmjerene na suzbijanje rada digitalnog tržišta droga predstavljaju velik izazov za brojne stručnjake koji se bave prevencijom zlouporabe ilegalnih tvari, od represivnog aparata pa sve do stručnjaka pomagačkih profesija koji zasigurno imaju veliku ulogu u osmišljavanju i implementaciji različitih preventivnih aktivnosti u ovoj domeni.

\section{UVOD}

Posljednjih nekoliko desetljeća globalna ekonomija prolazi kroz transformaciju u digitalnu ekonomiju u kojoj se stvaraju mogućnosti za pojavom radikalnih promjena u načinu rada, socijalizacije, stvaranju vrijednosti i tržišnom natjecanju (Franc, 2020.), a razvoj digitalnih platformi omogućio je i razvoj digitalnog tržišta drogom. Kenney i sur. (2019.) definiraju platforme kao virtualna mjesta na kojima s pomoću algoritama sudionici mogu samostalno djelovati, međudjelovati ili obavljati transakcije, a digitalne platforme djeluju kao posrednici koji omogućavaju interakciju između korisnika koji se nalaze na različitim stranama neke transakcije. Povijesno gledajući, nedopuštena trgovina drogom prvenstveno se odvijala u fizičkim prostorima gdje su postojala praktična ograničenja i granice, dok je razvoj novih tehnologija omogućio porast online trgovina na digitalnom tržištu s globalnim dosegom što ima potencijala proširiti granice nabave droge i osigurati prilike za one koji žele kupiti drogu. Također, digitalno tržište droge omogućuje sudionicima priliku nabavljati i prodavati drogu iz svog doma te tako izbjegavati kontakt »licem u lice«, a sami sudionici izvještavaju da im to osigurava razinu anonimnosti i osjećaj fizičke sigurnosti koji bi se u drugačijim okolnostima teško postigao (Martin, 2014.).

Razvoj digitalnog tržišta mijenja dinamiku prodajnog i kupovnog procesa te tako potencijalno otvara prostor za širu »publiku« i sudionike koji se vjerojatno međusobno ne poznaju. Međutim, neke aktivnosti ne mogu se odvijati na digitalnim platformama, poput procesa proizvodnje i fizičke transakcije koja se često odvija poštom.

U posljednjih nekoliko desetljeća, puno pažnje se posvećuje prodaji droga i drugih ilegalnih proizvoda i usluga na digitalnom tržištu tzv. dark neta (ili dark weba), odnosno kripto tržištima koja postoje u tzv. skrivenim dijelovima interneta te im nije moguće pristupiti preko standardnih internet preglednika (Wilson i Stevens, 2008.; Zekanović- Korona i Klarin, 2012.; van Hout i Birgham, 2014.; Wadsworth i sur., 2017.; Wadsworth i sur., 2018.) nego preko specifičnog softvera (npr. The Onion Router Tor) koji služi za preusmjeravanje internetskog prometa i otežavanje otkrivanja IP adrese. Osim toga, šifriranje i kodiranje valuta (npr. bitcoin) također omogućuje veliku 
razinu anonimnosti za kupce i prodavače na dark netu, a droga se dostavlja putem pošte čime se izbjegava direktan kontakt uključenih strana (EMCDDA, 2016.). lako neki autori (Barratt i sur., 2013.; Aldridge i De'cary-He'tu, 2014.; van Hout i Bingham, 2014.) smatraju da digitalizacija tržišta povezanog s drogom, zajedno s forumima koji omogućuju davanje savjeta korisnicima i ocjenjivanje prodavača i njihovih proizvoda, mogu smanjiti nasilje i kriminalitet na tržištu droga. Brzina kojom internet mijenja ovo tržište stavlja veliki izazov ispred službi koje se bave provedbom zakona, javnim zdravstvom te prevencijskim politikama.

Budući da se ovdje radi o rastućem i vrlo prilagodljivom fenomenu, koji svakako predstavlja sve veću javnozdravstvenu i sigurnosnu prijetnju, važno je pažnju usmjeriti na istraživanje problematike i načina rada digitalnog tržišta droga o čemu još uvijek postoje nepoznanice, a u prilog tome svjedoči i nedostatak znanstvene i stručne literature, posebice u Republici Hrvatskoj.

Svrha ovog rada je stoga dati uvid u neke čimbenike suvremenog tržišta droga te, unutar tog okvira, analizirati utjecaj digitalnog tržišta na strukturu i dinamiku tržišta droga. Cilj je pojasniti način funkcioniranja ovakvih tržišta čime bi se doprinijelo razvoju preventivnih aktivnosti u borbi protiv digitalnog tržišta drogom. Znanstvenim metodama analize, sinteze i kompilacije omogućit će se pojašnjavanje i razumijevanje čimbenika suvremenog tržišta droga kao i ključnih elemenata kripto tržišta te analizirati utjecaj navedenog tržišta na strukturu i dinamiku globalnih i lokalnih tržišta droge. Metodom dedukcije kritički će se formirati zaključci o utjecaju digitalnog tržišta droge na strukturu i dinamiku suvremenog tržišta te se sažeti preporuke za preventivno djelovanje u svrhu suzbijanja ovoga fenomena.

\section{ČIMBENICI VAŽNI ZA RAZUMIJEVANJE SUVREMENOG TRŽIŠTA DROGA}

Kako bi se mogao dobiti jasan uvid u suvremeno tržište droga, bitno je osvrnuti se na neke poteškoće u definiranju tržišta droga uopće te, sukladno tome, pojasniti pojam i ulogu kripto tržišta u procesima razvoja suvremenog tržišta droga.

Jedan od važnih nedostataka vezanih uz definiranje tržišta droga jest nedostatak usuglašenih definicija i razina tržišta te se one razlikuju od studije do studije.

Prema Ritterovoj (2006.) pojam »ilegalno tržište droga« naširoko se koristi u istraživanjima vezanim uz zlouporabu droga, a znači različite stvari različitim istraživačima. Burton i sur. (2014.) definiraju ilegalno tržište droga kao »pojam koji uključuje tri međusobno labavo povezana tržišta» - globalno ili »međunarodno tržište» koje uključuje proizvodnju droge i međunarodnu trgovinu; drugo, "srednje tržište» koje uključuje uvoz i veleprodajnu distribuciju droge na nacionalnoj razini i, treće, »lokalno 
tržište« koje uključuje distribuciju na maloprodajnoj razini (Coomber i Moyle, 2013.). Sličnu analizu tržišta droga dao je i Gaziarifoglu (2011.), ali s posebnim osvrtom na razlike s obzirom na zemljopisnu lokaciju i prirodu transakcije. Isti autor govori o "zatvorenim tržištima« gdje se prodavatelj i kupac međusobno poznaju, »otvorenim tržištima« u kojima se prodavatelj i kupac ne poznaju, »mobilnim tržištima» čija je karakteristika dogovor o transakciji putem mobilnih uređaja i tzv. »open air tržišta« gdje se distribucija obavlja u okviru dogovorenih geografskih područja.

Pregledom i analizom relevantne literature, evidentno je nekoliko čimbenika koji karakteriziraju suvremeno tržište droga:

1) Jačanje međusobne povezanosti različitih vrsta tržišta

- putevi trgovanja drogom mijenjaju se i prilagođavaju međunarodnim i nacionalnim politikama suzbijanja krijumčarenja ilegalnih tvari, razvijaju se sve kompleksniji kanali distribucije, neovisno o vrsti droge (EMCDDA, 2016.; Žunić, 2018.; Marković i Rastović, 2020.).

2) Razvijanje novih načina rada organiziranog kriminaliteta

- pojedinci, skupine i organizacije transnacionalnog organiziranog kriminaliteta prilagođavaju se promjenama na tržištu droga služeći se sofisticiranim metodama trgovine i sve više pojačavaju svoje djelovanje na digitalnom tržištu; prilagodbe su evidentirane i na tržištu kokaina na kojemu se, »u profilu međunarodnog krijumčara pojavljuje i potrošač, s izrazitim sklonostima nasilju i agresiji« (Klarić, 2008.: 222).

3) Globalizacija i razvoj novih tehnologija nezaustavljivo utječe na strukturu i dinamiku tržišta droga

- inovacije na tržištu i rastuća važnost kripto tržišta te razvoj informacijskih znanosti, mobilnih tehnologija i metoda šifriranja ubrzava i olakšava proces komunikacije i preprodaje, osobito novih psihoaktivnih tvari (Martin, 2014.; Gluić, 2016.; Jandrić Nišević i sur., 2016.; EMCDDA, 2020.)

- razvoj novih tržišta: u zemljama Latinske Amerike, Azije i Afrike raste potražnja, što se svakako odražava i na europsko tržište droge (EMCDDA, 2016.; EMCDDA, 2020.).

4) Promjene u dinamici različitih tržišta

- raste proizvodnja i uporaba sintetičkih droga, posebice amfetamina i metaamfetamina kao i tržište kokainom dok se intravenozna uporaba heroina, ali i općenito tržite heroinom u Europi smanjuje (povećava se broj supstitucijskog liječenja), za razliku od Sjeverne Amerike i pojedinih zemalja koje graniče s Europskom unijom gdje je detektirana pojačana uporaba opioida (Kruithof i sur., 2016.; EMCDDA, 2020.)

- povećanje potentnosti biljnog kanabisa i smole kanabisa koja od 2007. godine konstantno raste, iako se tržište kanabisa smatra relativno stabilnim 
od 2012. godine te je uglavnom ograničeno na maloprodajnu i lokalnu razinu (EMCDDA, 2016.; EMCDDA, 2020.)

- raste zlouporaba i nezakonita distribucija supstitucijske terapije, a evidentiran je i trend porasta broja nekontroliranih tvari kao i sve veći ulazak novih psihoaktivnih tvari na tržište, osobito sintetskih kanabinoida (Klarić, 2008.; Jandrić Nišević i sur., 2017.; Žunić, 2018.; EMCDDA, 2020.; Marković i Rastović, 2020.).

Nove psihoaktivne tvari (u daljnjem tekstu NPT) postaju interesno područje starim skupinama konzumenata, ali i potencijalno novim korisnicima, posebice adolescentima. Ured Ujedinjenih naroda za droge i kriminal (eng. United Nations Office on Drugs and Crime) navodi nekoliko njihovih glavnih karakteristika: (1) »oponašaju« efekte klasičnih droga, (2) predstavljaju prijetnju za javno zdravlje i (3) nisu kontrolirane Konvencijama UN-a (Marković i Rastović, 2020.: 301; Herceg Pakšić i Pakšić, 2020.). Ključni čimbenik u njihovoj proizvodnji je kemijski sastav zbog kojeg ne podliježu zakonskoj kontroli droga u punom smislu. Naime, proizvođači NPT-a nastoje pronaći legalne alternative zabranjenim tvarima koje bi kod konzumenata izazvale određene učinke, a ujedno bi bile i široko dostupne. Kako bi se dobila nova tvar i izašlo iz kažnjive zone, dovoljno je da se kemijskim putem neznatno izmijeni struktura zabranjenog proizvoda (od tuda i naziv »nove psihoaktivne tvari«). U kontekstu tržišta NPT-a, važno je napomenuti kako su Republika Hrvatska, kao i druge države članice EU-a posljednjih godina doživjele znatnu ekspanziju online trgovine upravo ovih vrsta tvari (osobito sintetskih kanabinoida) pri čemu znatnu ulogu igraju upravo tzv. skrivene internetske mreže ( EMCDDA, 2016.; Marković i Rastović, 2020.). Herceg Pakšić i Pakšić (2020.) te Marković i Rastović (2020.) navode kako se u Hrvatskoj nove psihoaktivne tvari pojavljuju najčešće pod nazivom osvježivača zraka, soli za kupanje, sredstava za čišćenje te gnojiva za cvijeće uz oznaku da nisu za konzumaciju, a osim na digitalnim platformama mogu se kupiti i u specijaliziranim trgovinama (eng. Smart shop) ili radnjama za trgovinu duhanskim proizvodima (eng. Tobacco shop). No, ono što je zabrinjavajuće je porast ovih tvari na hrvatskom tržištu te, u tom smislu, Herceg Pakšić i Pakšić (2020.) s pravom naglašavaju činjenicu kako sustavnih istraživanja o ovoj problematici koja bi bila temelj pro futuro legislative te ozbiljne prevencijske politike u Republici Hrvatskoj zapravo i nema.

Navedene značajke tržišta svjedoče o konstantnoj promjeni i prilagodbi njegove strukture i dinamike, sukladno trendovima, globalizaciji i razvoju novih tehnologija. Kriminalne organizacije razvijaju nove načine proizvodnje i distribucije ilegalnih tvari što predstavlja velik izazov u kreiranju međunarodnih i nacionalnih politika suzbijanja zlouporabe psihoaktivnih tvari. Valja naglasiti da se na maloprodajnoj razini trgovina i dalje odvija metodom »licem u lice«. Međutim, u okviru organiziranog kriminaliteta i kreiranja mreže distribucije droga, sve se više iskorištavaju prednosti digitalnog 
tržišta. lako internetske platforme za prodaju nezakonitih droga i dalje čine relativno malen dio ukupnog tržišta, njihova je važnost u posljednjih nekoliko godina sve veća.

\section{ŠTO JE KRIPTO TRŽIŠTE I KOJI SU NJEGOVI KLJUČNI AKTERI?}

Analizom recentne znanstvene i stručne literature, evidentno je kako se definiranje pojma kripto tržišta usmjerava na nekoliko temeljnih pojmova i aktivnosti: ponuda i potražnja ilegalnih tvari, digitalna platforma kao sredstvo komunikacije, nezakonita djelatnost te proces transakcije.

Kada govori o razvoju kripto tržišta, Martin (2014.) naglašava da je ovaj oblik tržišta nastao i razvio se u okviru hakerskih foruma na kojima korisnici koriste digitalno šifriranje u svrhu zaštite identiteta, a Aldridge i De'cary-He'tu (2016.) govore o online platformi na kojoj se razmjenjuju nezakonite ilegalne tvari.

Kripto tržište droga je oblik tržišta na kojemu se trguje različitim vrstama nezakonitih tvari, korisnicima je omogućena anonimnost, a postoji i mogućnost davanja povratnih informacija o trgovini što je od velike koristi sudionicima tržišta, smatraju Barrat i Aldridge (2016.).

Aldridge i De'cary-He'tu (2014.) u analizama kripto tržišta droga polaze od Mertonovog (1938., prema Brown i sur., 2010.) razumijevanja pojma »inovator« koji time opisuje pojedince koji se odlučuju na kriminalne aktivnosti, a u suvremenom kriminološkom kontekstu misli se na one pojedince čija su poslovanja uspješnija od konkurencije te su izvan dosega policije. Također, zaključuju da, iako navedena inovacija može doći iz različitih područja i sfera, u posljednja dva desetljeća dolazi upravo s interneta.

Platforme kripto tržišta izgledaju i funkcioniraju jednako kao i legalna tržišta na internetu (eBay, Amazon) dopuštajući svojim korisnicima pretraživanje i uspoređivanje različitih proizvoda i proizvođača, a ono što ih razlikuje od legalnih tržišta jest činjenica da svojim korisnicima osiguravaju anonimnost, smatraju Škare (2006) i Turudić, Milić i Štulina (2017.).

Jedna od prvih i najpoznatijih takvih stranica je Silk Road koja je s radom započela u 2011. godini i radila je uspješno sve do 2013. godine kada je zatvorena od strane Federal Bureau of Investigation ( $u$ daljnjem tekstu FBI). Kroz 2014. godinu, broj takvih stranica poput Silk Roada je sve više rastao pa su tako nastale stranice kao što su Hydra, Evolution, Pandora, Agora i Silk Road 2.0 koje su se borile kako bi zadobile ponovno povjerenje kupaca i proizvođača. Branwen (2015., prema Aldridge i De'cary-He'tu, 2016.) navodi da su se u 2014. godini otvorila 43 nova nezakonita tržišta, a zatvorilo se njih 46 od čega se samo njih šest zatvorilo kao posljedica provedbe zakona, dok 
su se ostala zatvorila zbog prijevara od strane administratora. U srpnju 2017. godine srušeno je tržište AlphaBay, najveće dosadašnje tržište, a iste je godine obustavljeno još jedno veliko tržište, Hansa. Bez obzira na tu činjenicu, analiza Europskog centra za praćenje droga i ovisnosti o drogama (eng. European Monitoring Centre for Drugs and Drug Addiction, u daljnjem tekstu EMCDDA) i Europola pokazuje da su se već godinu dana nakon toga prihodi i opseg trgovanja povezani s prodajom droga na kripto tržištu vratili na razine koje su prethodile operaciji za provedbu zakona (EMCDDA, 2020.). Od 2010. godine do danas detektirano je preko 100 različitih kripto tržišta droga na tzv. skrivenom dijelu interneta (eng. dark web). Soska i Christin (2015.), Aldridge, Stevens i Barratt (2017.) te EMCDDA (2020) ističu da su takva tržišta iznimno otporna i prilagodljiva te da njihovo uklanjanje od strane službi za provedbu zakona najčešće rezultira samo premještanjem na neku drugu platformu.

Prije pojave online kupovine, distribucija droge na maloprodajnoj razini odvijala se uglavnom na točno dogovorenim lokacijama, no razvojem tehnologije i kripto tržišta stvorilo se sigurnije okruženje, premještanjem poslovanja s ulice na internet (Penny, 2016.). Upravo pojavom digitalnog tržišta stvoreno je dinamično tržište u kojemu sudionici mogu neometano komunicirati u svim fazama poslovanja.

Ono što je ključno za funkcioniranje i razvoj kripto tržišta jest činjenica da svi njegovi akteri moraju biti informatički pismeni te imati posebna znanja i vještine koje im omogućuju sudjelovanje na ovakvoj vrsti tržišta, smatraju Barrat i Aldridge (2016.). Marković i Rastović (2020.) navode kako ovakva, u potpunosti anonimna trgovina, podrazumijeva profesionalno znanje o informacijskim tehnologijama, ali zbog višestruke zarade akterima tog tržišta nije problem platiti stručne usluge što posljedično dovodi do znatnih problema u otkrivanju i dokazivanju kaznenih djela.

Analizirajući vrste kriminaliteta u digitalnom svijetu, Penny (2016.) objašnjava četiri središnja aktera digitalnog tržišta drogom: kupac, prodavač, administrator i davatelj internetskih usluga.

Naglašava se važnost reputacije prodavača (na temelju čega ga kupac odabire) te odnos povjerenja na relaciji kupac - prodavač. Prodavači na kripto tržištima dužni su platiti proviziju administratoru za svaku provedenu transakciju za posao koordinacije prodaje i upravljanje čitavim sustavom (van Buskirk i sur., 2016.).

Van Slobbe (2016.) definira administratora kao upravitelja internet stranice koji je odgovoran za sve što se tamo događa - od odobravanja računa, izrade novih kategorija proizvoda pa sve do zabrane prodaje određenih dobara i pružanja učinkovite zaštite. Davatelj internetskih usluga je akter koji se spominje u kontekstu zaštite i podržavanja tržišta, ali o kojemu nema dovoljno podataka vezano za usluge koje pruža.

Analizirajući način funkcioniranja i dinamiku dubokog weba (eng. deep web), van Haut (2014.) i Bago (2016.) navode da se prodaja droge na ovoj razini može odviti unutar samog tržišta, unutar decentralizirane mreže ili između pojedinaca, 
ali i naglašavaju da se na razini deep weba ne nalaze isključivo stranice na kojima se odvijaju kriminalne aktivnosti. Dio deep weba »specijaliziran« za razvijanje kriminogenih sadržaja, pa tako i kripto tržišta drogom, odvija se na još dubljoj razini - na razini dark weba ili dark neta (Gilbert i Dasgupta, 2017.; Žunić, 2018.; EMCDDA, 2020.).

Silk Road je najpoznatije i najtraženije kripto tržište i, iako se razlikuje po stupnju pružene anonimnosti, Silk Road je osigurao prodavačima i kupcima sličnu infrastrukturu za provođenje transakcija koje im osiguravaju i ostala digitalna tržišta kao što je, primjerice, eBay, s profesionalnim raspravama o mehanizmima odluke, korištenjem ocjenjivanja prodavača (eng. vendors) i kupaca, postavljanjem foruma za raspravu i slično. lako se mnogo proizvoda reklamira na Silk Roadu, upravo rekreacijske droge poput kanabisa, MDMA-a, LSD-a i nekih propisanih lijekova pokazale su se najpopularnijima (Barratt i sur., 2014.; Buxton i Bingham, 2015.). Silk Road je održao anonimnost svojih aktivnosti i lokacije kombinirajući dvije tehnologije, Tor i bitcoin, pri čemu Tor omogućava anonimnu komunikaciju između prodavača i kupca, a bitcoin se može koristiti za olakšavanje anonimnih transakcija te kao valuta razmjene (Bojić, 2017.).

Kripto tržište je omogućilo nove prilike, ali i brojne izazove za institucije koje se bave smanjenjem štete, tretmanom i provedbom zakona. Rezultati relevantnih istraživanja (Barratt i sur., 2013.; van Haut, 2014.; Hardy i Norgaard, 2016.) ističu da je postojanje Silk Roada pomoglo konzumentima u smanjenju štete u odnosu na tržišta droge koja se odvijaju na ulici, a kao primjere za to navode prodaju visokokvalitetnih proizvoda s malim rizikom od kontaminacije, distribuciju proizvoda koje su testirali proizvođači, dijeljenje izvještaja o kvaliteti droge i online rasprave o načinima smanjenja štete.

Online praćenje predstavlja novi pristup praćenja tržišta droga za službe koje se bave provedbom zakona, dok su njihove strategije uglavnom fokusirane na slom tržišta što uključuje smanjenje povjerenja u anonimnost te identificiranje, uhićenje i kazneni progon prodavača na kripto tržištima. Otvorenije taktike uključuju upoznavanje korisnika s činjenicom prisutnosti policije na tim stranicama te osiguravanje da rušenje tih tržišta bude medijski popraćeno. Na razini Europske unije razvijen je program ITOM (eng. Illegal Trade on Online Marketplaces) koji je uspostavio posebnu mrežu kojoj je jedan od zadataka uspostaviti efektivne načine borbe protiv nezakonitih razmjena unutar digitalnog tržišta (Nasseri, 2014.; Ilić i sur., 2017.; EMCDDA, 2020.).

Dio suzbijanja tržišta ilegalnih droga na deep webu zahtijeva usku suradnju službi kriminaliteta droga i službi koje se bave suzbijanjem kibernetičkog kriminala te inovativne pristupe redukciji takvih tržišta. Pri tome je iznimno važna suradnja s poštanskim i kurirskim službama putem kojih se droga kupljena na internetu doprema do krajnjih korisnika. Stoga je danas više nego ikada važno praćenje stanja i razvoja novih trendova kako bi se pravovremeno moglo odgovoriti na nove pojave. 


\section{Utjecaj kripto tržišta droga na globalna i lokalna tržišta drogom}

Kripto tržišta droga nisu samo rezultat nove tehnologije, već su kombinacija četiri vrste sigurnosnih mehanizama koji se nikada prije nisu koristili zajedno, smatraju Bunjaku, Gjorgieva-Trajkovska i Miteva-Kacarski (2017.). Prva je da zahtijevaju od svojih korisnika vršenje novčanih transakcija u virtualnim valutama jer je takve transakcije puno teže pronaći i njihova uporaba nije kontrolirana od strane regularnih agencija. Drugo, kripto tržišta droga od korisnika zahtijevaju da koriste protokole za postizanje anonimnosti (kao što su Tor ili I2P) kako bi sakrili svoj identitet prilikom spajanja na kripto tržište, a oni koriste te protokole kako bi sakrili svoju IP adresu i tako otežali mogućnost provoditeljima zakona da sruše njihove stranice. Ostala dva sigurnosna mehanizma usmjerena su na omogućavanje osjećaja sigurnosti i povjerenja po pitanju transakcije kupaca.

Procjene koje su napravili Christin (2013., prema Aldridge i De'cary-He'tu, 2016.) te Aldridge i De'cary-He'tu (2016.) na Silk Roadu, govore da su takva tržišta doprinijela državnom proračunu sa 16,7 milijuna američkih dolara u 2012. godini i 89,7 milijuna dolara u 2013. godini. S druge strane, procjene koje se često navode u medijima, a proizlaze iz istraživanja Ureda Ujedinjenih naroda za droge i kriminal (u daljnjem tekstu UNDOC) protežu se od 300 bilijuna do 1,3 trilijuna američkih dolara godišnje te se iz svega ovoga može zaključiti da, na prvi pogled, kripto tržišta neće imati velik utjecaj na tržišta drogom (UNDOC, 2016.). Međutim, Martin (2014., prema Aldridge i De'cary-He'tu, 2016.) ističe da kripto tržišta transformiraju konvencionalnu prodaju droga putem ubrzavanja procesa stvaranja globalne mreže počinitelja. Drugim riječima, čini se vjerojatnim da bi vrsta trgovine olakšana kripto tržištima mogla nadopunjavati (umjesto da zamijeni) konvencionalna tržišta drogom pomoću, primjerice, omogućavanja kupcima nabavljanje većeg opsega tvari koje im prije nisu bile dostupne.

Neki od čimbenika koji predstavljaju ograničenja za rast kripto tržišta su aktivnosti službi za provedbu zakona kao i gubitak povjerenja kod proizvođača i kupaca koji su bili posljedica prijevara od strana administratora takvih stranica. No, postoji još čimbenika koji postavljaju ograničenja rastu kripto tržišta, a oni se glavnom odnose na potrebnu razinu tehnoloških vještina kako bi se pristupilo takvim tržištima (primjerice, razumijevanje kako koristiti Tor, virtualne valute i slično).

Nadalje, nabavljanje droge putem kripto tržišta zahtijeva planiranje unaprijed, a neki konzumenti droga nemaju volju planirati konzumiranje unaprijed već preferiraju nabaviti drogu od dobro poznatoga nabavljača, licem u lice, i u trenutku kada im se javi želja i potreba za konzumacijom, smatraju Aldridge i De'cary-He'tu (2015.). 
Još jedno ograničenje predstavlja i činjenica da se droge nabavljene preko kripto tržišta moraju slati poštom, a s tim dolazi i rizik za otkrivanjem, koji je rezultat aktivnosti nadgledanja i zapljena koje se događaju na granicama zemlje, točnije u poštanskim i carinskim uredima. Briga oko rizika slanja i primanja nezakonitih tvari preko pošte veća je u situacijama kada se droge šalju preko međunarodnih granica budući da su tada veće šanse da će paket biti pregledan i zaplijenjen. Istraživanje temeljeno na podacima prikupljenima na Silk Roadu pokazuje da prodavači općenito biraju slati unutar granica (čak $71 \%$ američkih proizvođača), osim ako postoje jaki push faktori za drugačijim postupanjem (Aldridge i De'cary-He'tu 2016.). Isti autori su analizom dobivenih podataka izdvojili šest takvih čimbenika: nedovoljna »domaća potražnja za nezakonitim drogama, percipirana niža aktivnost agencija za provedbu zakona što proizvođačima osigurava sigurnije međunarodno djelovanje, niži BDP po stanovniku što ograničava snagu kupnje lokalnih kupaca, niže ocjene proizvođača zbog čega im je otežano natjecanje na nacionalnoj razini s proizvođačima koji su bolje ocijenjeni, raspon proizvoda ponuđenih od strane proizvođača odmjeren prema broju ponuđenih listi i prodaja težinski manjih paketa budući da će oni lakše proći kontrole na državnim granicama te granicama međudržavne asocijacije (EU), unutar šengenskog režima.

lako kripto tržišta i dalje imaju manji tržišni udio u cjelokupnoj trgovini drogama, dokazi pokazuju da se šire. Barratt i sur. (2014.), prema Aldridge i De'cary-He'tu, 2016.) navode rezultate istraživanja koji pokazuju da je u Australiji, SAD-u i Ujedinjenom Kraljevstvu čak 7\%, 10\% i 18\% uzorka konzumiralo nezakonite tvari koje su nabavili putem Silk Roada, pri čemu kao kupci cijene lak pristup, kvalitetu i opseg proizvoda koji im se nudi na kripto tržištima, jednako kao i percepciju tih tržišta kao sigurnijih od klasičnih »uličnih « tržišta. S druge strane, prodavači smatraju da im je mogućnost za uhićenjem značajno smanjena (Ciancaglini i sur., 2013.; Aldridge i De'cary-He'tu, 2016.; Čekeravec, Dvorak i Čekeravac, 2016.). Istraživanje o strukturi i dinamici tržišta droga u Republici Hrvatskoj koje su proveli Jandrić Nišević i sur. (2017.) jednim je svojim dijelom obuhvatilo i učestalost korištenja digitalnih platformi u kupovini i prodaji ilegalnih tvari. Na uzorku od 156 osuđenih ovisnika u Kaznionici u Lepoglavi, Kaznionici u Glini i Zatvoru u Zagrebu, 6\% ispitanika je izjavilo da je kupovinu i prodaju droga realiziralo preko dark weba. lako se ovdje radi o relativno niskom udjelu ispitanika, procjena stručnih djelatnika koji se dugi niz godina bave problematikom ovisnosti je da je ta brojka u praksi puno veća.

U opsegu u kojem digitalna tržišta dozvoljavaju direktnu vezu između proizvođača i kupaca koji konzumiraju drogu, kripto tržišta mogu služiti da izbace neke srednje ili veleprodajne razine u lancu tržišta drogama (Martin, 2013., prema Aldridge i De'cary-He'tu, 2016.; Finklea, 2017.) i/ili mogu reducirati veze u lancu između proizvođača i krajnjeg korisnika. Ecstasy i njemu slične droge dominirale su veleprodajnim aktivnostima na kripto tržištima, no primijećene su i značajne veleprodajne aktivnosti 
benzodiazepima i stimulansa koji se dobivaju na recept. U manjim brojkama, ali i dalje značajnim, u veleprodaji se pojavljuju i kokain, metamfetamini i heroin. lako su proizvođači na kripto tržištima locirani u 41 zemlji, veleprodaja je potvrđena u samo trećini zemalja, uključujući Kinu, Nizozemsku, Kanadu i Belgiju (Martin, 2014.).

Aldridge i De'cary-He'tu (2016.) upućuju na činjenicu da proizvođači daju značajne popuste na velike online kupovine na kripto tržištima što omogućuje profitabilniju offline preprodaju. Kupci kupuju velike količine droge iz više razloga pri čemu neki od njih mogu biti stvaranje zalihe za duže vrijeme ili »socijalna opskrba« u kojoj jedna osoba kupuje drogu za sebe i prijatelje, ali i za preprodaju (Jeriček, 2002.; Aldridge i sur., 2011.; Coomber i Moyle, 2013., prema Aldridge i De'cary-He'tu, 2016). Navedeni autori također smatraju da su direktne veze između proizvođača i kupaca više moguće kod vrste droga gdje proizvođači malih razmjera mogu raditi sami bez međunarodnih mreža velikih razmjera (tu pripadaju, primjerice, kanabis i neke halucinogene droge koje je lako proizvesti, kao što su halucinogene gljive i DMT), a takve direktne veze proizvođač - konzument manje su karakteristične za droge poput heroina i kokaina čija distribucija zahtijeva međunarodne mreže velikih razmjera. Drugi autori (Ormsby, 2016.; Aldridge i De'cary-He'tu, 2016.; Munksgaard, Demant i Branwen 2016.) upućuju na online kulturu smanjene štete koja je bila očigledna na Silk Roadu te visoku razinu zadovoljstva kupaca kvalitetom nabavljenih nezakonitih tvari koja je bila superiornija kvaliteti nezakonitih tvari nabavljenih na ulici pri čemu je istraživanje Burtona i sur. (2014., prema Aldridge i De'cary-He'tu, 2016.) utvrdilo da je čistoća kokaina bila 70,4\% u usporedbi s 38\% čistoće kokaina distribuiranog na ulicama Ujedinjenog Kraljevstva.

Prije pojave mogućnosti nabave velike količine droga online, preprodavači su morali imati veze i izgrađene odnose povjerenja s preprodavačima srednje razine i/ili uvoznicima kako bi bili u mogućnosti osigurati proizvod (Dundović, 1998.; McCharty i Hagan, 2001.; Morselli, 2001., prema Aldridge i De'cary-He'tu, 2016.) te su morali imati dobru reputaciju (Topalli i sur., 2002., prema Aldridge i De'cary-He'tu, 2016.). S pojavom kripto tržišta, gotovo bilo tko s osnovnim tehnološkim vještinama, može pristupiti zalihama nezakonitih tvari. U eri kripto tržišta, kod kupaca i proizvođača je važnije imati vještine pismenog izražavanja, davati dobre usluge kupcima i imati dobru reputaciju koja se zadobiva putem pozitivnih recenzija. Istraživanja (Aldridge i De'cary-He'tu, 2014.; Gústafsson, 2016.) pokazuju da će korisnici kripto tržišta uključiti preprodavače droga koji stvaraju zalihu za preprodavanje na konvencionalnom tržištu (eng. offline) i iz tih razloga, kripto tržišta ostaju ukorijenjena u konvencionalna tržišta droge, zajedno s proizvođačima koji nabavljaju offline kako bi prodavali online. Dakle, zahtjev za poduzimanjem ili veleprodajnih ili maloprodajnih aktivnosti u offline tržištu znači da korisnici kripto tržišta mogu i dalje biti žrtve nasilja povezanog s takvim transakcijama. 
Nova vrsta trgovine drogom vjerojatno je slobodnija od nasilja koje se inače povezuje s tradicionalnim tržištima droge - fizičko nasilje kao oblik sekundarnog kriminaliteta povezanog s drogom (Schober, 2015.; Soska i Christin, 2015.; Rhumorbarbe i sur., 2016.; Jandrić Nišević i sur., 2017.), no šteta se može manifestirati i u drugim oblicima kriminalnih aktivnosti kao što su prijetnje, narušavanje reputacije, doxing (hakiranje i zatim prijetnje otkrivanjem identiteta), ucjene, krađe i zlostavljanje preko interneta. Naposljetku, nasilje povezano s tržištem droga može biti i kulturološki, politički i socijalno uvjetovano (Aldridge i De'cary-He'tu, 2016.; Aldrige i sur., 2017.; Finklea, 2017.) prije nego što izrasta iz funkcije samog ilegalnog tržišta.

\section{SUZBIJANJE DIGITALNOG TRŽIŠTA DROGE TE MOGUĆNOSTI PREVENTIVNOG DJELOVANJA}

Strategije suzbijanja kripto tržišta uključuju suradnju više različitih institucija i specijaliziranih službi. S obzirom na ograničene mogućnosti identificiranja glavnih aktera takvih tržišta, politika suzbijanja digitalnog tržišta trebala bi, između ostalog, biti usmjerena na otkrivanje i presretanje pošiljki kao i na ometanje Tor mreže i sličnih preduvjeta poslovanja ovakvih mreža, smatraju Jandrić Nišević i sur. (2017.). Mikulin (2019.) ističe postojanje brojnih prepreka koje neposredno utječu na neodgovarajući odgovor u suzbijanju kibernetičkog kriminala te, s tim u vezi i na suzbijanje digitalnog tržišta droge. Neke od njih su nedostatak globalne konvencije i globalnog pravnog okvira, kao i određivanje granice između efikasnog nadzora u svrhu prevencije kibernetičkog kriminala i narušavanja osobnih prava fizičkih i pravnih osoba. Međunarodna suradnja na polju kibernetičke prijetnje nužno se javlja u vidu specijaliziranih organizacija, često regionalnog ili višenacionalnog karaktera, kao i globalnih organizacija (Mikulin, 2019.). U Republici Hrvatskoj suzbijanje kibernetičkog kriminala odvija se unutar Uprave kriminalističke policije u sklopu koje od 2008. godine djeluje Policijski nacionalni ured za suzbijanje korupcije i organiziranog kriminala (u daljem tekstu PNUSKOK). Unutar PNUSKOK-a postoji Odjel za visokotehnološki kriminalitet koji zajedno sa Službom kriminaliteta droga djeluje na aktivnostima suzbijanja digitalnog tržišta droge.

U svrhu organizacije i provođenja što efikasnijih aktivnosti suzbijanja digitalnog tržišta droge, na svjetskoj razini provode se interdisciplinarna istraživanja koja uglavnom koriste metodologiju pod nazivom web-o-metric koja svakim novim istraživanjem kroz suradnju kriminalista, kriminologa i informatičara unapređuje načine praćenja digitalnog traga, a time i obavljenih transakcija, ponuda, cijena, kvalitete droga te različitih tema korisnika kripto tržišta, iskazanih uglavnom na forumima. Međutim, sve se više javlja potreba osmišljavanja i drugačijih pristupa, više usmjerenih na su- 
dionike kripto tržišta droga. Stoga se među metodama prikupljanja podataka može pronaći mnoštvo globalnih online upitnika, kojima se pozivaju svi koji nešto znaju o problematici kripto tržišta na podjelu informacija, čime se do neke mjere apelira i na one koji na tržištu ne sudjeluju ili ga ne podržavaju, ali o njemu nešto znaju (Žunić, 2018.). Etnografske studije korisnika nastoje objasniti aktivnosti na kripto tržištu iz pozicije kupaca te dublje razumjeti geografske i kulturološke specifičnosti područja ili skupina. Navedene alternative web-o-metric pristupa imaju zajednički izazov, a to je pronalazak relevantnih ispitanika i nošenje s problemom istinitosti, odnosno relevantnosti podataka. S druge strane, samo je dio važnih podataka dostupan analizom digitalnog traga (na čemu se temelji web-o-metric metodologija), pri čemu nedostaju mnogi važni podaci za razumijevanje populacije koja bira ovakvu aktivnost u trgovini drogama, bilo kao trgovci ili kao kupci.

Promoviranje znanja o razvoju digitalnog tržišta droge važno je i za pomagačke profesije (socijalni radnici, socijalni pedagozi, psiholozi), osobito stručnjake koji rade na području prevencije i tretmana ovisnika o drogama. Naime, mnogo stručnih suradnika u probacijskom i zatvorskom sustavu, ali i sustavu socijalne skrbi ili nevladinom sektoru sve češće dolazi u kontakt s korisnicima nezakonitih tvari nabavljenih preko digitalnog tržišta te su im potrebna neka nova znanja i drugačiji pristupi u radu s takvim korisnicima. Osim toga, stručnjaci navode nedostatak vlastitih znanja o terminologiji i načinu funkcioniranja digitalnog tržišta što im otežava rad s takvim korisnicima i usporava uspostavljanje kvalitetnog terapijskog odnosa.

Uprava kriminalističke policije, osobito Služba kriminaliteta droga te Odjel za visokotehnološki kriminalitet svakako imaju glavnu ulogu i specifičnu metodologiju u suzbijanju digitalnog tržišta droge, no stručnjaci pomagačkih profesija isto tako imaju dužnost, ali i odgovornost u razvoju raznih preventivnih aktivnosti koje mogu biti od velike važnosti u smanjenju rada tržišta na digitalnim platformama. Takve aktivnosti mogu se odvijati na nekoliko razina: (1) razvijanje znanja o različitim aspektima digitalnog tržišta - povezanosti takvog tržišta s tradicionalnim, već donekle poznatim, tržištima, načinu rada i ulozi glavnih aktera na digitalnom tržištu što se postiže objavljivanjem znanstvenih i stručnih radova na navedenu temu, dodatnim edukacijama i drugoj vrsti stručnog usavršavanja, (2) izrada sveobuhvatne analize korisnika digitalnog tržišta droga u Republici Hrvatskoj provođenjem istraživanja na različitim uzorcima u različitim vremenskim razdobljima (obuhvatiti što veći broj ispitanika, osobito mlađe do srednje životne dobi), primjerice, anonimnim online upitnikom koristeći brojne mogućnosti društvenih mreža; provesti dubinsko istraživanje na populaciji ovisnika u zatvorskom, probacijskom i zdravstvenom sektoru te u suradnji s brojnim nevladinim udrugama koje u svojoj domeni imaju i rad s ovisnicima o drogi i (3) temeljem rezultata istraživanja osmisliti potencijalne specifične pristupe u tretmanu ako se pokaže potreba. Navedene aktivnosti svakako zahtijevaju kom- 
pleksan, multidisciplinarni pristup problematici koji može biti izazovan i dugotrajan, ali je neophodan ukoliko se želi umanjiti šteta koju uzrokuju digitalna tržišta droge, posebice ako se uzme u obzir trenutni nedostatak znanstvene i stručne literature o ovoj temi u Republici Hrvatskoj.

U kontekstu analize korisnika tržišta droga u Republici Hrvatskoj, svakako valja izdvojiti istraživanje Herceg Pakšić i Pakšić (2020.) o poznavanju i konzumaciji sintetičkih droga na populaciji osječkih srednjoškolaca provedenog u suradnji s Odjelom prevencije Policijske uprave osječko-baranjske 2015. te 2017. godine, a koje ukazuje na znatnu izloženost i poznavanje tog tipa droga među mladom populacijom (više od $80 \%$ ih je upoznato s pojmom i pojavom osvježivača zraka, a više od $20 \%$ ih je i probalo). Kada se uzme u obzir podatak da je upravo prodaja ovakvih droga na internetu u posljednjih godina u porastu (Marković i Rastović, 2020.), opravdano je zaključiti da će u budućnosti sve više mladih konzumenata, osim u specijaliziranim trgovinama (gdje trenutno najčešće nabavljaju) nabavljati i ovakvu vrstu droge online. Rezultati istraživanja o uporabi sredstava ovisnosti na općoj populaciji iz 2015. i 2016. godine ukazuju na činjenicu da se vrlo rano počinje eksperimentirati s novim psihoaktivnim tvarima, u prosjeku već od petnaeste godine života (Zrilić, 2016.). Jandrić Nišević i sur. (2017.) navedene su nalaze potvrdili istraživanjem strukture i dinamike tržišta droga u RH na uzorku maloljetnih ispitanika te zamijetili sve veću uporabu digitalnih platformi prilikom kupnje i distribucije novih psihoaktivnih tvari. Navedena istraživanja potvrđuju važnost analize suvremenog tržišta droga i njegovih korisnika u različitim vremenskim razdobljima kako bi se dobio uvid u specifičnosti novih trendova te se na vrijeme moglo pristupiti razvoju preventivnih aktivnosti, posebice prema mladima koji se nalaze u povećanom riziku.

\section{ZAKLJUČAK}

Analiza suvremenog tržišta droge pokazuje svu kompleksnost i dinamičnost ovog područja te ukazuje na sve veći utjecaj digitalnih platformi na razvoj i promjene unutar ovoga sustava.

S obzirom da kripto tržište učvršćuje globalnu mrežu kupaca i prodavača, moguće je naslutiti da će važnost ovakvog načina trgovanja nezakonitim tvarima porasti te smanjiti prepreke za ulazak i djelovanje na takvim platformama. Razvojem informatičkih tehnologija sasvim sigurno će se razvijati i sve sofisticiranije metode djelovanja kripto tržišta droga što će zasigurno imati utjecaja i na tradicionalna tržišta, ako se uzme u obzir međusobna interakcija ove dvije vrste tržišta. Kupovina veće količine nezakonitih tvari na digitalnom tržištu mogla bi se odraziti na preprodaju takvih proizvoda na tradicionalnim, »licem u lice« tržištima. Svakako ne treba zane- 
mariti utjecaj kripto tržišta na prodaju novih psihoaktivnih tvari, ali i na povećanje broja potencijalnih kupaca zbog »prednosti« koje ovakva vrsta tržišta nude, a to su, prije svega, anonimnost i percepcija sigurnosti od otkrivanja kriminalnih aktivnosti. Uzimajući u obzir rezultate istraživanja, potencijalni kupci su svakako mlađe dobne skupine, osobito konzumenti tzv. novih psihoaktivnih tvari čija prodaja sve više raste na nezakonitim digitalnim platformama. Temeljem analize znanstvene i stručne literature opravdano je zaključiti da kripto tržišta droge neće u potpunosti zamijeniti tradicionalna tržišta, ali će sasvim sigurno olakšati trgovinu nezakonitih tvari i na taj način nadopuniti trgovinu na konvencionalnim tržištima omogućavanjem nabavljanja veće količine nezakonitih tvari koje su prije bile teže dostupne.

Suzbijanju digitalnog tržišta droga svakako treba pristupiti interdisciplinarno, imajući u vidu prilagodljivost i složenost ovakve vrste tržišta. Upravo ove karakteristike digitalnog tržišta droga znatno otežavaju organizaciju i provedbu aktivnosti usmjerenih na otkrivanje i gašenje digitalnih platformi na kojima se odvija nezakonita prodaja droge.

Osiguravanje adekvatnih preventivnih aktivnosti i pravnih mehanizama predstavlja globalni, međunarodni problem kojemu se treba posvetiti puno više pažnje kako bi se osiguralo praćenje trendova na digitalnom tržištu droge jer se brzim razvojem tehnologije konstantno pojavljuju novi načini poslovanja i unaprjeđenje ovog tržišta.

Od kako je 2013. godine prvi put otkrivena internetska stranica Silk Road, mnogo se otkrilo o tržištu droga putem interneta. Međutim, svako novo razotkrivanje takvih i sličnih stranica često stvara novu prilagodbu djelovanja i razvoj kreativnosti svih aktera kripto tržišta. Stoga, samo sveobuhvatnim razumijevanjem problema, unaprjeđenjem istraživačkih i multidisciplinarnih pristupa može se »uhvatiti u koštac» s ovim fenomenom.

\section{LITERATURA}

1. Aldridge, J. \& De'cary-He'tu, D. (2014). Not an 'eBay for Drugs': The cryptomarket silk road as a paradigm shifting criminal innovation. Preuzeto s: https://papers. ssrn.com/sol3/papers.cfm?abstract_id=2436643 (26.2.2020.).

2. Aldridge, J. \& De'cary-He'tu, D. (2015). Cryptomarkets: The darknet as an online drug market inovation. Preuzeto s: http://daviddhetu.openum.ca/files/ sites/39/2017/04/Nesta-Final-Report.pdf (26.2.2020.).

3. Aldridge, J. \& De'cary-He'tu, D. (2016). Hidden wholesale: The drug diffusing capacity of online drug cryptomarkets. International Journal of Drug Policy, 35 (1), 7-15. https://doi.org/10.1016/j.drugpo.2016.04.020 
4. Aldridge, J., Stevens, A. \& Barratt, M. J. (2017). Will growth in cryptomarket drug buying increase the harms of illicit drugs? Preuzeto s: https://www.researchgate. net/publication/318852751_Will_growth_in_cryptomarket_drug_buying_increase_the_harms_of_illicit_drugs (26.2.2020.).

5. Bago, N. (2016). Deep Web. Završni rad. Varaždin: Sveučilište Sjever, Sveučilišni centar Varaždin.

6. Barratt, M. J. \& Aldridge, J. (2016). Everything you always wanted to know about drug cryptomarkets* (*but were afraid to ask). International Journal of Drug Policy, 35 (81), 1-6. https://doi.org/10.1016/j.drugpo.2016.07.005

7. Bojić, B. (2017). Stanje i perspektive kriptovaluta. Svarog, 15, 184-197. https:// doi.org/10.7251/SVR1715184B

8. Brown, S., Esbensen, F. A. \& Geis, G. (2010). Criminology: Explaining crime and it's context. New York: New Providence.

9. Bunjaku, F., Gjorgieva-Trajkovska, O. \& Miteva-Kacarski, E. (2017). Cryptocurrencies-advantages and disadvantages. Preuzeto s: http://eprints.ugd.edu. $\mathrm{mk} / 18707 / 1 /$ Cryptocurrencies.pdf (5.1.2020.).

10. Buxton, J. \& Bingham, T. (2015). The rise and challenge of dark net drug markets. Policy Brief, 7 (2), 1-24.

11. Ciancaglini, V., Balduzzi, M., Goncharov, M. \& McArdle, R. (2013). Deepweb and cybercrime: It's not all about TOR. Preuzeto s: http://www.trendmicro.de/ media/wp/deepweb-and-cybercrime-whitepaper-en.pdf (10.1.2020.).

12. Čekeravac, Z., Dvorak, Z. \& Čekeravac, P. (2016). Da li je »tamni internet« dubok i taman? FBIM Transactions, 4 (2), 53-65.

13. Doležal, D. \& Jandrić Nišević, A. (2017). Mogućnosti i izazovi u istraživanju tržišta ilegalnim drogama. Anomija društva i posljedice. Banja Luka: Centar modernih znanja, 473-485.

14. Dundović, D. (1998). Ilegalni promet i trgovina opojnim drogama. Hrvatski ljetopis za kazneno pravo i praksu, 5 (2), 605-624.

15. EMCDDA-Europol (2013). EU drug markets report: A strategic analysis. Luxembourg: Publications Office of the European Union.

16. EMCDDA (2016). Europsko izvješće o drogama 2015: Trendovi i razvoj. Luksemburg: Ured za publikacije Europske unije.

17. EMCDDA (2020). Europsko izvješće o drogama 2019: Trendovi i razvoj. Luksemburg: Ured za publikacije Europske unije.

18. Finklea, K. (2017). Dark Web. Preuzeto s: https://fas.org/sgp/crs/misc/R44101. pdf (5.1.2020.).

19. Franc, S. (2020). Politika tržišnog natjecanja u digitalnoj ekonomiji. Ekonomska misao i praksa, 2, 491-512. https://doi.org/10.17818/EMIP/2020/2.9 
20. Gaziarifoglu, Y. (2011). Risk factors of drug dealing in open-air markets. RTM Insights, 13 (1), 1-3.

21. Gilbert, M. \& Dasgupta, N. (2017). Silicon to syringe: Cryptomarkets and disruptive innovation in opioid supply chains. International Journal of Drug Policy, 46, 160-167. https://doi.org/10.1016/j.drugpo.2017.05.052

22. Gluić, H. (2016). Nove psihoaktivne tvari: Sintetski kanabinoidi i sintetski katinoni. Diplomski rad. Rijeka: Medicinski fakultet Sveučilišta u Rijeci.

23. Gústafsson, B. J. (2016). Darknet market usage among Swedish residents. Preuzeto s: https://skemman.is/bitstream/1946/24913/1/Darknet\%20market\%20 usage\%20among\%20swedish\%20residents.pdf (13.2.2020.).

24. Hardy, R. A. \& Norgaard, J. R. (2016). Reputation in the Internet black market: An empirical and theoretical analysis of the Deep Web. Journal of Institutional Economics, 12 (3), 515-539. https://doi.org/10.1017/S1744137415000454

25. Herceg Pakšić, B. \& Pakšić, I. (2020). Izloženost mladih novim vrstama droga i izazovi prikladne pravne reakcije. Godišnjak Akademije pravnih znanosti Hrvatske, XI (1), 63-78. https://doi.org/10.32984/gapzh.11.1.4

26. Ilić, M., Spalević P., Spalević, Ž., Veinović, M. \& Aleja K. S. A. (2017). Deep web i dark web - potreba ili zloupotreba. INFOTEH-JAHORINA, 16, 635-639.

27. Jandrić Nišević, A., Doležal, D., Maračić, D., Novak, T. \& Šuljak, B. (2016). Izvješće o projektu »/straživanje tržišta droga u Republici Hrvatskoj - uloga sekundarnog kriminaliteta«. Zagreb: Ured za suzbijanje zlouporabe droga Vlade Republike Hrvatske.

28. Jandrić Nišević, A., Doležal, D., Novak, T., Lotar Rihtarić, M., Jeđud, I. (2017). Izvješće o projektu »Struktura i dinamika tržišta droga u Republici Hrvatskoj«. Zagreb: Ured za suzbijanje zlouporabe droga Vlade Republike Hrvatske.

29. Jeriček, H. (2002). Internet i ovisnost o internetu u Sloveniji. Medijska istraživanja, 8 (2), 85-101.

30. Kenney, M., Rouvienen, P., Seppala, T. \& Zysman, J. (2019). Platforms and industrial change. Industry and Innovation, 26, 871-879. https://doi.org/10.1080/1 3662716.2019.1602514

31. Klarić, D. (2008). Današnji trendovi kriminala u svezi sa zlouporabom droga i važne karakteristike kriminalističko-metodičkog pristupa u suzbijanju. Policija i sigurnost, 17 (3-4), 219-242.

32. Kruithof, K., Aldridge, J., Décary Hétu, D., Sim, M., Dujso, E. \& Hoorens, S. (2016). Internet-facilitated drugs trade: An analysis of the size, scope and the role of the Netherlands. RAND Corporation, California.

33. Marković, D. \& Rastovć, D. (2020). Tržište droga - utjecaj sintetskih kanabinoida i drugih novih psihoaktivnih tvari na trenutačno stanje. Policija i sigurnost, 29 (3), 297-312. 
34. Martin, J. (2014). Lost on the Silk Road: Online drug distribution and the »Cryptomarket«. Criminology \& Criminal Justice, 14 (3), 351-367. https://doi. org/10.1177/1748895813505234

35. Mikulin, R. (2019). Kaznenopravna zaštita od kibernetičkog kriminala i uloga davatelja telekom usluga. Diplomski rad. Zagreb: Fakultet prometnih znanosti Sveučilišta u Zagrebu.

36. Munksgaard, R., Demant, J. \& Branwen, G. (2016). A replication and methodological critique of the study '»Evaluating drug trafficking on the Tor network'". International Journal of Drug Policy, 35, 92-96. https://doi.org/10.1016/j.drugpo.2016.02.027

37. Nasseri, R. (2014). An investigation of cryptomarkets: Assessing the online drugs trade from the perspectives of Australian Health and law enforcement agencies. Preuzeto s: https://www.researchonline.mq.edu.au/vital/access/services/ Download/mq:42116/SOURCE1?view=true (21.2.2020.).

38. Ormsby, E. (2016). Silk Road: Insights from interviews with users and vendors. In: European Monitoring Centre for Drugs and Drug Addiction: The internet and drug markets. Luxembourg: Publications Office of the European Union, 61-67.

39. Penny, C. (2016). The organization of cyber crime. York University Criminological Review, 1, 67-85.

40. Rhumorbarbe, D., Staehli, L., Broséus, J., Rossy, Q. \& Esseiva, P. (2016). Buying drugs on a Darknet market: A better deal? Studying the online illicit drug market through the analysis of digital, physical and chemical data. Forensic Science International, 267, 173-182. https://doi.org/10.1177/0022042619872955

41. Ritter, A. (2006). Studying illicit drug markets: Disciplinary contributions, International Journal of Drug Policy, 17(6), 453-463. https://doi.org/ 10.1016/j. drugpo.2006.09.004

42. Schober, S. (2015). Deep dark web of the internet iceberg. Preuzeto s: https:// scottschober.com/deep-dark-web-of-the-internet-iceberg (7.1.2020.).

43. Soska, K. \& Christin, N. (2015). Measuring the longitudinal evolution of the online anonymous marketplace ecosystem. Preuzeto s: https://www.usenix. org/system/files/conference/usenixsecurity15/sec15-paper-soska-updated. pdf (15.1.2020.).

44. Škare, V. (2006). Internet kao novi kanal komunikacije, prodaje i distribucije za segment mladih potrošača. Market-Tržište, 18 (1-2), 29-40.

45. Turudić D. A., Milić, J. \& Štulina, K. (2017). Korištenje kriptovaluta u međunarodnom poslovanju. Zbornik Sveučilišta Libertas, 1-2 (1-2), 191-210.

46. van Buskirk, J., Naicker, S., Bruno, R., Burns, L., Breen, C. \& Roxburgh, A. (2016). Drugs and the Internet. Sydney: National Drug and Alcohol Research Centre. 
47. van Hout, M. C. \& Bingham, T. (2014). Responsible vendors, intelligent consumers: Silk Road, the online revolution in drug trading. International Journal of Drug Policy, 25, 183-189. https://doi.org/10.1016/j.drugpo.2013.01.005

48. van Slobbe, J. (2016). The drug trade on the deep web: A law enforcement perspective. In: European Monitoring Centre for Drugs and Drug Addiction: The internet and drug markets. Luxembourg: Publications Office of the European Union, 77-83. https://doi.org/10.1016/j.drugpo.2013.10.009

49. Zekanović-Korona, Lj. \& Klarin, T. (2012). Internet: Informacijsko-komunikacijska platforma za nove načine putovanja. Medijska istraživanja, 18 (2), 59-72.

50. Zrilić, M. (2016). Sintetske droge: Nove psihoaktivne supstance u rukama djece. Zbornik radova za medicinske sestre. Split: Hrvatska proljetna psihijatrijska škola, 86-90.

51. Žunić, I. (2018). Razvoj kripto tržišta kao novog oblika tržišta u svijetu. Diplomski rad. Zagreb: Edukacijsko-rehabilitacijski fakultet Sveučilišta u Zagrebu.

52. Wadsworth, E., Drummond, C., Kimergard, A. \& Deluca, P. (2017). A market on both "sides" of the law: The use of the hidden web for the sale of new psychoactive substances. Human Psychopharmacology Clinical and Experimental, 32 (3), 1-7. https://doi.org/10.1002/hup.2596

53. Wadsworth, E., Drummond, C. \& Deluca, P. (2018). The dynamic environment of crypto markets: The lifespan of new psychoactive substances (NPS) and vendors selling NPS. Brain Sciences, 8 (46), 1-9. https://doi.org.10.3390/brainsci8030046

54. Wilson, L. \& Stevens, A. (2008). Understanding drug markets and how to Influence them. The Beckley Foundation Drug Policy Programme. 
Anita Jandrić Nišević

Dalibor Doležal

Tihana Novak

\section{MODERN DRUG MARKET - THE INFLUENCE OF THE DIGITAL MARKET ON THE STRUCTURE AND DYNAMICS OF THE DRUG MARKET}

\section{SUMMARY}

The structure of the modern drug market is a complex phenomenon in which the constant flow of production, supply and demand of illegal substances results in increasingly dynamic development and trends, and which is under a great influence of globalization and the development of new technologies, especially the Internet. During the last several decades the Internet, as an important facilitator on the aforementioned market, has enabled a wide access to a broad range of information and has thus become a necessary communication tool for the development of criminal activities connected to the drug market. As an invisible, hidden side of the Internet, and under the disguise of anonymity, the crypto market as a form of a digital market offers new possibilities and ways of trafficking of illegal substances and in that manner takes over monopoly from classic ways of drug traffic ("face to face"). The paper analyses modern scientific knowledge about the manner in which the crypto drug market is functioning, as well as its influence on the structure and dynamics of the modern drug market, with the purpose of reflection on prevention activities that could eliminate such types of crime.

Research suggests that the traditional drug market will not disappear with the development of crypto markets, but that both markets will complement one another, at which the activity in the digital market will become more frequent due to larger possibilities of protecting the identities of its main operators. Activities focused on combating the digital market operation represent a great challenge for numerous experts dealing with prevention of illegal substance abuse, from the police to the professionals in helping professions who certainly have a great part in designing and implementing different preventive activities in this area.

Key words: modern drug market; digital market; crypto market; dark net

\section{(c) (1) $\odot$}

Međunarodna licenca / International License:

Creative Commons Attribution-NonCommercial-NoDerivatives 4.0. 